\title{
Hydrological Modeling to Evaluate Future Climate Change Impacts in Sind River Basin, India
}

\author{
Boini Narsimlu, Ashvani K. Gosain, and Bhagu R. Chahar
}

\begin{abstract}
This research work aims to assess the impact of future climate change on water resources availability in Sind river basin, India using Hydrological model SWAT. Future climate projections under PRECIS RCM generated outputs with IPCC SRES A1B Scenarios have been used. Model calibration and validation has been carried out with average mean monthly stream flow observations recorded at three gauge stations (Pachauli, Seondha and Bhind). First thirteen years (1987-99) stream flow observations have been used for calibration with a initial 3 years (1987-89) data as warm up period then calibrated for next 10 years and model has been validated for the consequent 6 years $(2000-05)$ with measured values. The model simulations with evaluation statistics shows a very good performance of stream flow predictions with $\mathbf{R}^{2}$ values ranged from $0.83-0.92$, NSE from $0.81-0.89$ and PBIAS from $\mathbf{- 1 2 . 0 8}$ to $\mathbf{- 2 4 . 1 9}$ for the observed and simulated values of stream flow during calibration and validation. Results show that evapotranspiration (ET) across the Sind river basin is increasing from baseline to mid century $(5 \%)$ and to end century $(6 \%)$ and the increase in precipitation in end century $\mathbf{( 1 8 \% )}$ indicates that more extreme high intensity events may be expected due to climate change.
\end{abstract}

Index Terms-SWAT model, calibration and validation, PRECIS RCM and climate change on stream flow.

\section{INTRODUCTION}

Change in surface air temperature and rainfall over a long period of time is known as climate change and it is a global problem. It is likely to impact all the natural ecosystems as well as health which leads to a reduction in global food grains production. In India rapid growing population and improving living standards increases the pressure on our water resources. According to IPCC (2007) [1] the climate change projections over India indicates that there would be a rise in temperature up to $3^{0} \mathrm{C}$ and precipitation may likely to be increased by $10-20 \%$ over Central India by the end of this century. These projected changes in climate would increase the water scarcity would decrease the production in agriculture with a serious implication on livelihoods. Eckhardt and Ulbrich (2003) [2] used climate change scenarios that resulted in

Manuscript received July 14, 2017; revised January 16, 2018.

Boini Narsimlu is with the Department of Civil Engineering, Indian Institute of Technology Delhi, New Delhi, India. $\mathrm{He}$ is also with ICAR-Central Research Institute for Dryland Agriculture, Hyderabad 500059, India (e-mail: narsimlu@yahoo.com, narsimlu.boini@icar.gov.in, narsimlu04@gmail.com).

Ashvani K. Gosain and Bhagu R. Chahar are with the Department of Civil Engineering, Indian Institute of Technology Delhi, New Delhi, India (e-mail: gosain@civil.iitd.ac.in, chahar@civil.iitd.ac.in,br.chahar@gmail.com). diminutive effect on mean annual stream flow, as increased atmospheric $\mathrm{CO}_{2}$ levels reduce stomatal conductance thus increasing potential evapotranspiration. Impact of climate change on water resources were evaluated by Ashraf Vaghefi et al., (2013) [3] in Karkheh River Basin in Iran using SWAT with future climate data generated from Canadian Global Coupled Model for scenarios A1B, B1 and A2 for mid century period of 2020-2040. The results show that freshwater availability would be increased from 1716 to 2670 $\mathrm{m}^{3} / \mathrm{capita} /$ year in northern part of KRB, in spite of projected increase in population (28\%) by 2025 under SRES B1 scenario.

Rahman et al., (2012) [4] applied SWAT in Southern Ontario basin with Canadian Regional Climate Model (CRCM) generated daily future data under SRES A2 scenario. Model results indicated that the average annual stream flow may increase by $12 \%$ when compared to baseline period. Gosain et al., (2006) [5] simulated the impacts climate change scenarios on stream flows of 12 major river basins in India, ranging in size from 1,668 to $87,180 \mathrm{~km}^{2}$ for the period 2041-2060. Surface runoff was found to be decreased and the severity of both floods and droughts were increased due to impact of future climate change projections. In another study SWAT applied at continental level in African by Faramarzi et al. 2013 [6]. Future climate projections applied were generated from four IPCC emissions scenarios (A1FI, A2, B1, and B2) under five GCMs (HadCM3, PCM, CGCM2, CSIRO2 and ECHAM4). The results indicated that in Africa, decrease in blue and green water resources. These variations has a considerable impact on the economic development and agricultural, which lead to vulnerability and food security. Meng et al. (2008) [7] for the upper reaches of Yangtze River, China using Variable Infiltration Capacity (VIC) model and applied five GCMs generated future climate change scenarios derived from Representative Concentration Pathway 4.5 (RCP4.5). Study outcomes indicated, a little decrease in stream flow in January to June and in contrary there is a drastic increase in stream flow during the months of August to October.

In another study Narsimlu et al. 2013 [8] applied SWAT model to Upper Sind River Basin, India with PRECIS-RCM generated AIB scenarios for the period for baseline, mid and end centuries. Results indicated that average annual stream flow could increase by $16.4 \%$ for mid century and a significant increase of $93.5 \%$ by end century compare to baseline. Hence the evaluation of future climate change impacts is essential on sustainable water resources management. Hydrological model (SWAT) has been applied to evaluate the impact of future climate change on water resources in Sind river basin. 


\section{STUDY AREA}

Sind River is a tributary of Yamuna River which flows through the states of Madhya Pradesh and Uttar Pradesh. The Sind originates on the Malwa plateau in Vidisha district M.P and flows north-northeast and confluences in Yamuna river. It has a total stream network length of 470 kilometers with a drainage area of $27,856 \mathrm{~km}^{2}$ (Fig. 1 . The climate of the region is characterized by hot and dry summer and cool winter. The minimum temperature during the winter goes up to $3^{\circ} \mathrm{C}$ and maximum in summer goes up to $48^{\circ} \mathrm{C}$. The annual precipitation varies from 800 to $1000 \mathrm{~mm}$. The natural vegetation comprises tropical dry deciduous and thorn forests The region is under irrigated agriculture as well as traditional rainfed agriculture. The soils in general are characterized by Clay, Clay Loam, Sandy Loam and Silt Loam. Land use of the river basin contains cropped areas $45 \%$, grasslands $25 \%$, evergreen forest $10 \%$, and water body $1.0 \%$, snow $0.5 \%$, built up $0.5 \%$ and fallow $18 \%$ of total area.

A large area under this region is very low productivity with subsistence agriculture and excessive runoff. Various crops grown are Paddy, Wheat, Jowar, Grams, Soybean, Sugarcane and Cotton. On main streams of the Sind River, there are three gauging stations located at Bhind, Seondha and Pachauli for recording of stream flows which were monitored by CWC, MoWR, GOI.

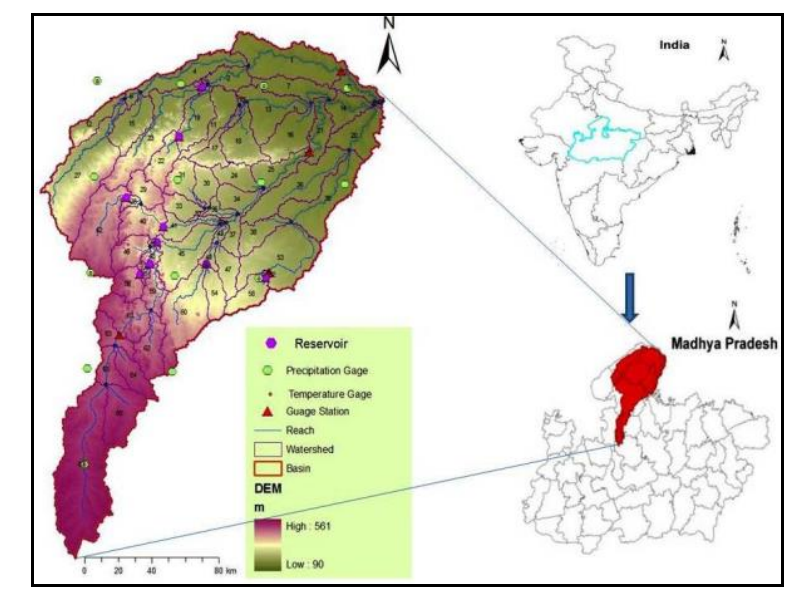

Fig. 1. Location map of Sind river basin, sub basin, DEM, reservoirs and gauge stations.

\section{Methodology}

SWAT model is a continuous, long term, physically based, distributed model developed to assess impacts of climate and land management on hydrological components, sediment loading, and pollution transport in unguaged watersheds (Arnold et al., 1998) [9]. In the SWAT model, a watershed is divided into sub basins. Sub basins are further divided into a series of uniform hydrological response units (HRUs) based on unique combination of soil, slope and landuse. HRU delineation can minimize simulations by lumping similar soil and land use areas into a single unit (Neitsch et al., 2005) [10]. Different hydrological components like sediment yield and nutrient cycles are simulated for each HRU and then aggregated for the sub basins. Hydrological components simulated in the SWAT model include evapotranspiration (ET), surface runoff, percolation, lateral flow, groundwater flow (return flow), transmission losses, and ponds (Arnold et al., 1998) [9].

The ArcSWAT2009 version has been used for simulations in the present study. The spatial inputs, DEM, SRTM data at $90 \mathrm{~m} \times 90 \mathrm{~m}$ resolution regridded was obtained from USGS site http://srtm.csi.cgiar.org has been used for delineation of watershed and to create drainage pattern. The land use land cover digital layers data has been obtained from National Remote Sensing Centre (NRSC), GOI. The soils data has been obtained from National Bureau of Soil Survey and Land Use Planning (NBSSLUP), Indian Council of Agricultural Research (ICAR), GOI. Weather data has been obtained from IMD for a period of 35 years (1961 to 2005) and incorporated in the model. Future weather data generated by the Hadley Centre for Climate prediction at U.K. using PRECIS RCM for IPCC SRES A1B scenarios with a resolution of $0.44^{\circ} \times 0.44^{\circ}$, latitude by longitude grid points were obtained from IITM, Pune has been utilized for Baseline (1961-1990), Mid Century (2021-2050) and End Century (2071-2098) in present study. The observed stream flow data of the watershed has been obtained from Central Water Commission, MoWR, GOI.

The model was calibrated and validated at Pachauli, Seondha and Bhind gauge stations. Initial runs were carried out for the period (1987-2000) with the first 3 years (1987-1989) used as a warm-up period and next ten years (1990-2000) for calibration. Then the model was validated for the consequent years from 1992-1999. The model performance was evaluated using goodness-of-fit statistics such as the coefficient of determination $\left(\mathrm{R}^{2}\right)$, Nash-Sutcliffe model efficiency (NSE), RSR and PBIAS. The results of monthly flows when compare to the observed flow during calibration and validation were shown in Fig. 2. These figures illustrate that the SWAT simulated stream flows were almost matched very well with the observed values and the model is able to simulate stream flows. Commonly used efficiency criteria, such as $\mathrm{R}^{2}$, NSE, RSR and PBIAS were used to assess the capability of the model simulations. These performance indicators (Table I) of the model during calibration period were found to be $0.83,0.78,0.47$ and -3.46 at Pachouli, 0.83,0.82,0.44 and 12.08 at Seondha and at Bhind $0.87,0.83,0.42$ and -12.16 respectively, which indicates a good performance of the model. During the validation period, the $\mathrm{R}^{2}$, NSE, RSR and PBIAS were found to be $0.87,0.83,0.42$ and -24.19 at Pachouli, 0.87,0.87,0.32 and -21.06 and at Bhind gauge station 0.97, 0.96, 0.21 and -19.06, respectively, which also confirms a good performance of the model during the validation period as per the criteria of Moriasi et al.,(2007) [11]. The calibration and validation performance for SWAT model is considered acceptable when $\mathrm{R}^{2}$ and NSE are greater than 0.5 and with the absolute value of PBIAS ranges from 15 to 25 (Moriasi et al., 2007) [11].

\section{RESUlTS AND DisCUSSION}

\section{A. Sensitivity Analysis}

A set of model parameters for sensitivity analysis have been selected by referring to SWAT documentation (Neitsch et al. 2002) [12] and significant references (Eckhardt and 
Arnold 2001 [13]; Lenhart et al. 2002 [14]; Santhi et al. 2001 [15]; White and Chaubey 2005 [16]; van Griensven et al. 2006) [17]. The parameters with highest sensitivity have been used to calibrate and validate the model. The SWAT hydrological parameters which are critical for the model performance are GW DELAY, ALPHA BF, GWREVAP, GWQMN, RCHRG_DP, CN2, ESCO, EPCO, CH N2, CH K2, ALPHA BNK, SOL AWC, SOL K, SOL BD, and
SFTMP. The sensitivity analysis predicted that most sensitive parameters for the Sind river basin are Groundwater delay, Soil available water capacity (SOL AWC), Runoff curve number for moisture condition II (SCS CN2), Base flow alpha factor (ALPHA BF), Groundwater revap coefficient (GWREVAP) and Soil evaporation compensation factor $(\mathrm{ESCO})$.

TABLE I: SWAT MODEL RESUltS OF AVERAGE MONTHLy STREAM FLOW OUTPUT STATISTICS OF SIND RIVER BASIN

\begin{tabular}{|c|c|c|c|c|c|c|c|c|}
\hline \multirow{2}{*}{$\begin{array}{l}\text { Gauge } \\
\text { station }\end{array}$} & \multicolumn{2}{|c|}{$\mathbf{R}^{2}$} & \multicolumn{2}{|c|}{ NSE } & \multicolumn{2}{|c|}{ RSR } & \multicolumn{2}{|c|}{ PBIAS } \\
\hline & Calibration & Validation & Calibration & Validation & Calibration & Validation & Calibration & Validation \\
\hline Pachauli & 0.83 & 0.86 & 0.78 & 0.83 & 0.47 & 0.41 & -3.46 & -24.2 \\
\hline Seondha & 0.83 & 0.86 & 0.81 & 0.87 & 0.43 & 0.37 & 12.08 & -21.06 \\
\hline Bhind & 0.86 & 0.97 & 0.83 & 0.96 & 0.41 & 0.2 & -12.16 & -19.05 \\
\hline
\end{tabular}

\section{Calibration and validation at Pachauli gauge station}

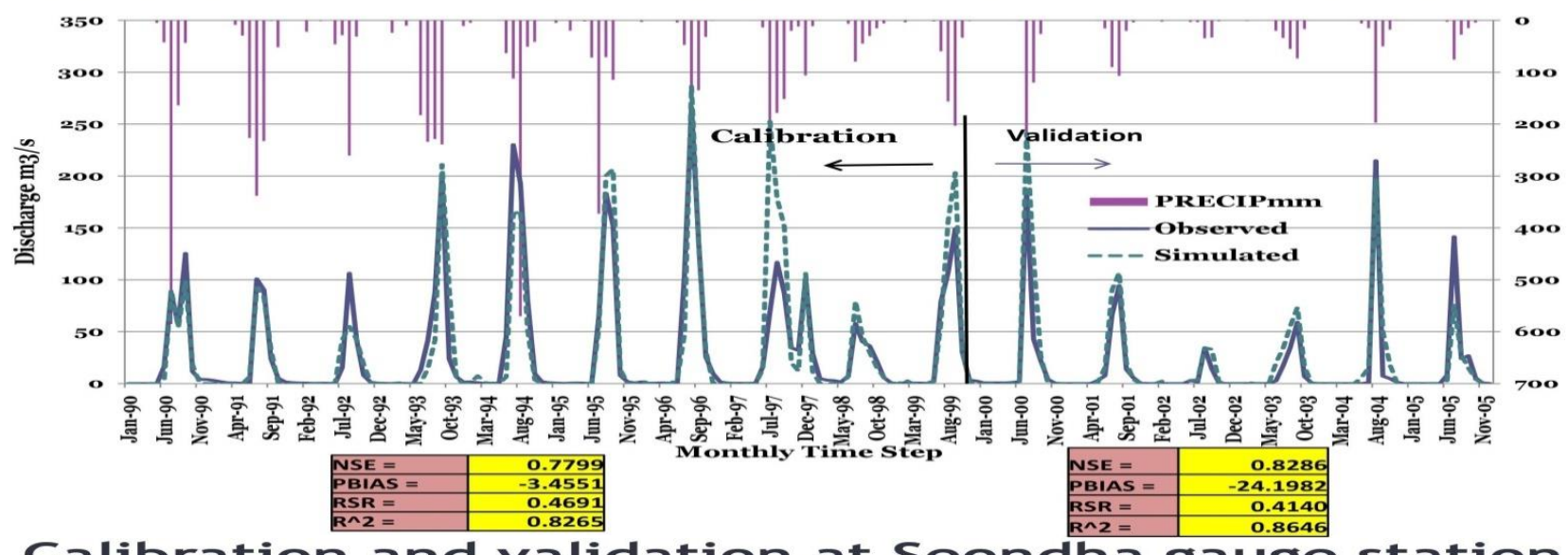

Calibration and validation at Seondha gauge station

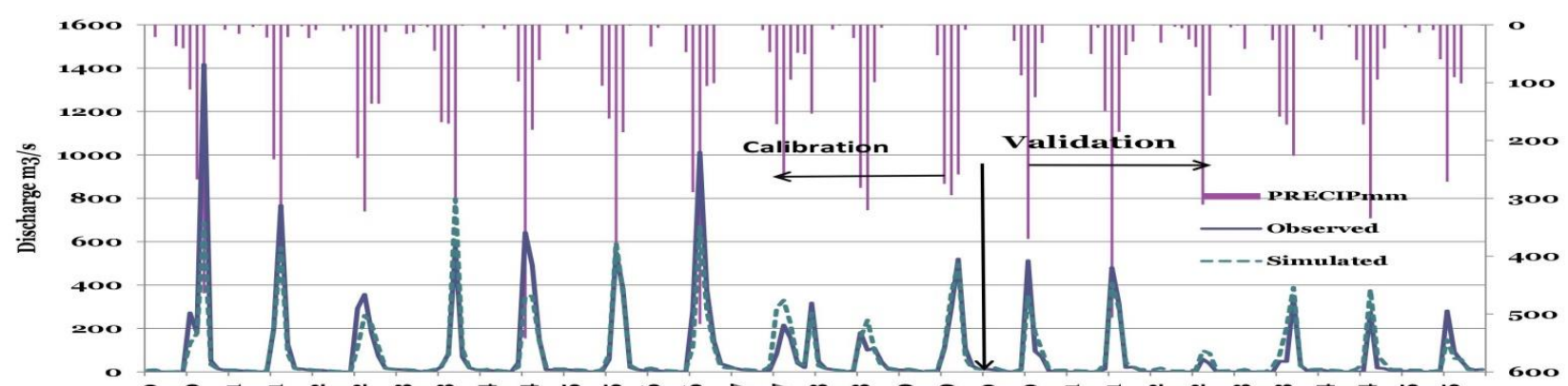

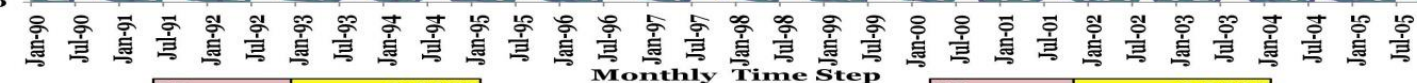
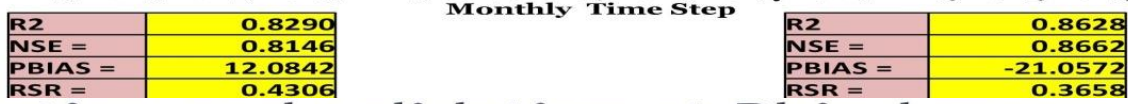

Calibration and validation at Bhind gauge station

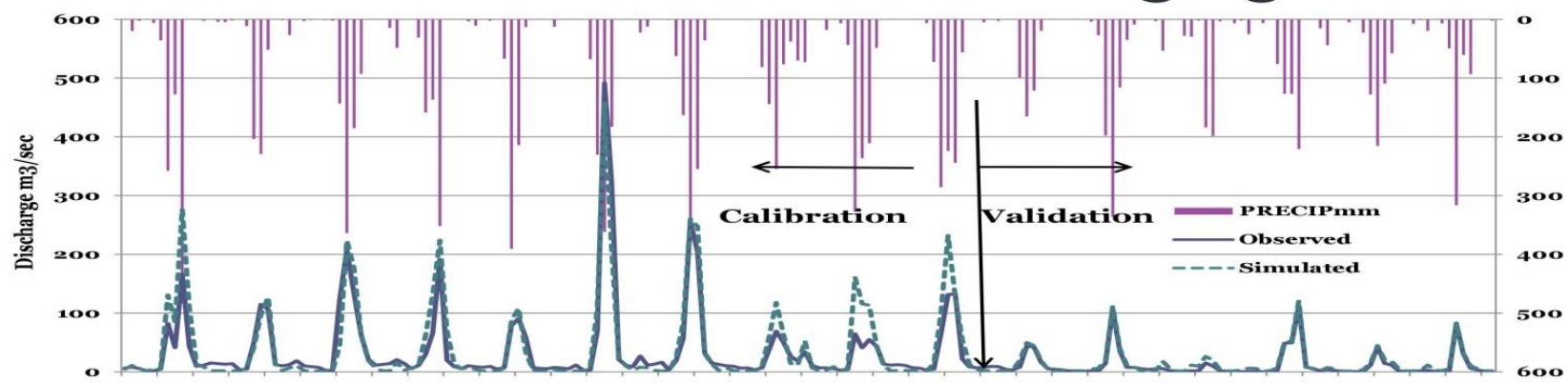

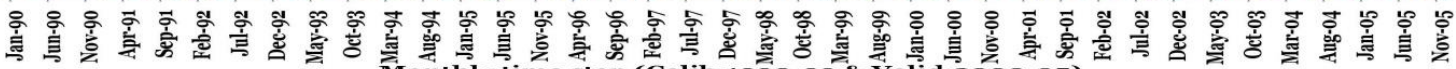
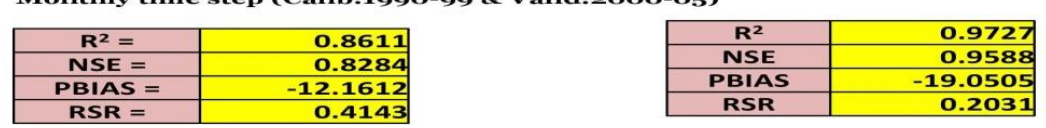

Fig. 2. Calibration and validation at Pachauli, Seondha and Bhind gauge stations for monthly observed and simulated discharge in cumecs. 


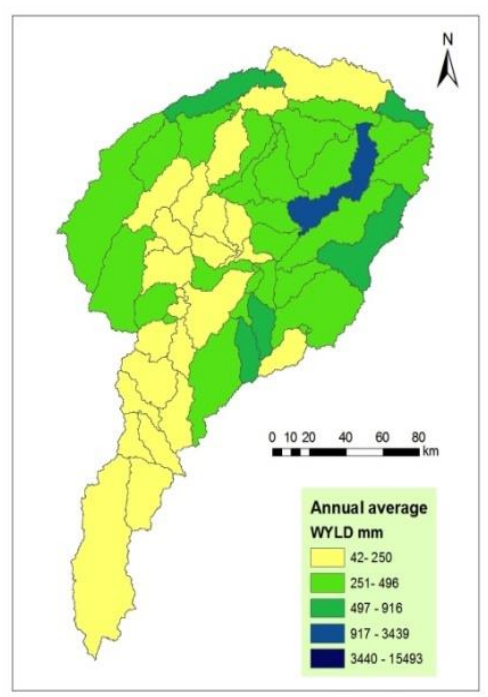

(a)

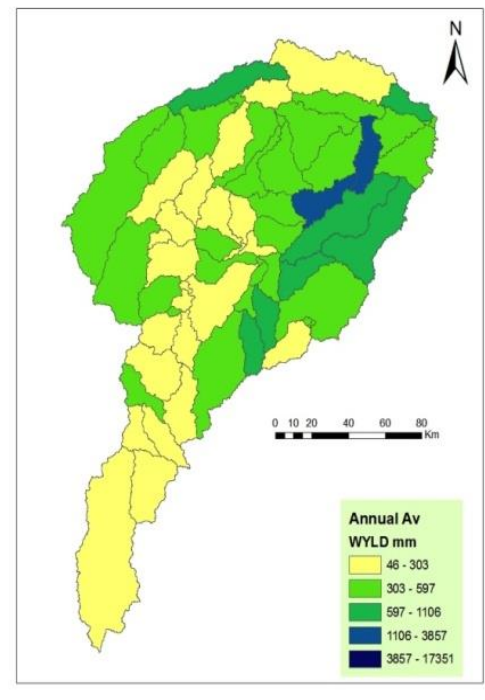

(b)

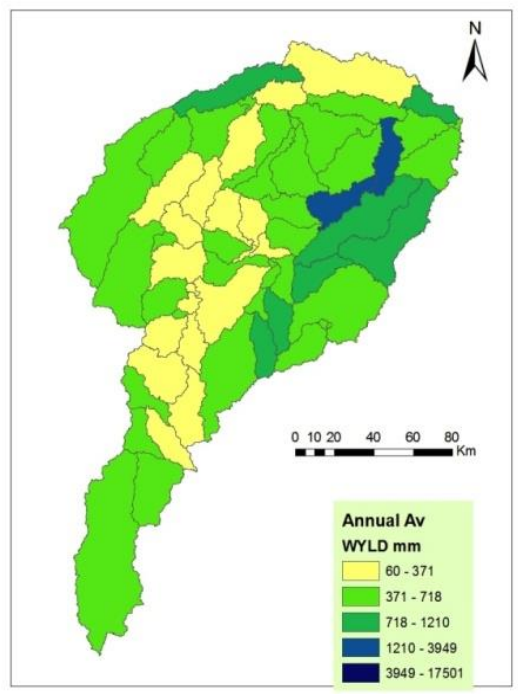

(c)

Fig. 3.1. Av. annual water yield for a. Baseline 1961-1990, b.Midcentury 2021-2050 and c. Endcentury 2071-2098.
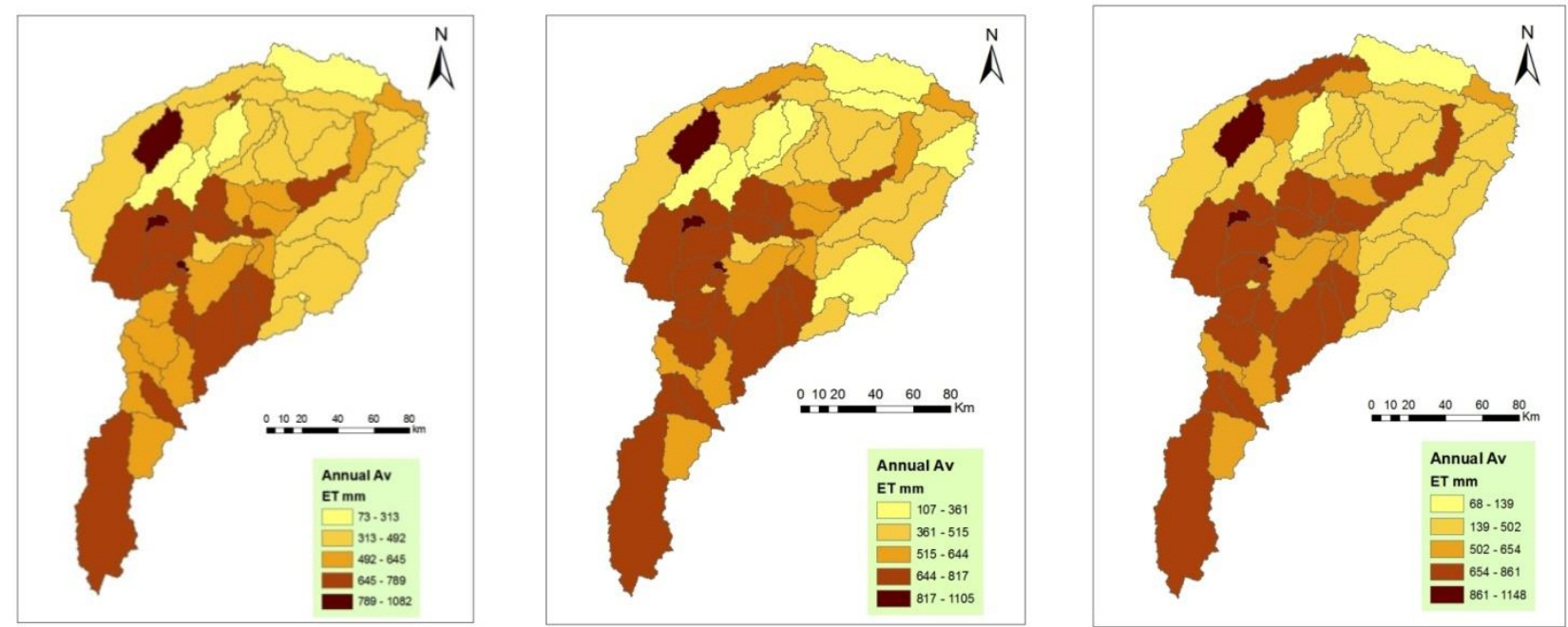

Fig. 3.2. Average annual ET baseline 1961-1990, midcentury 2021-2050 and endcentury 2071-2098.
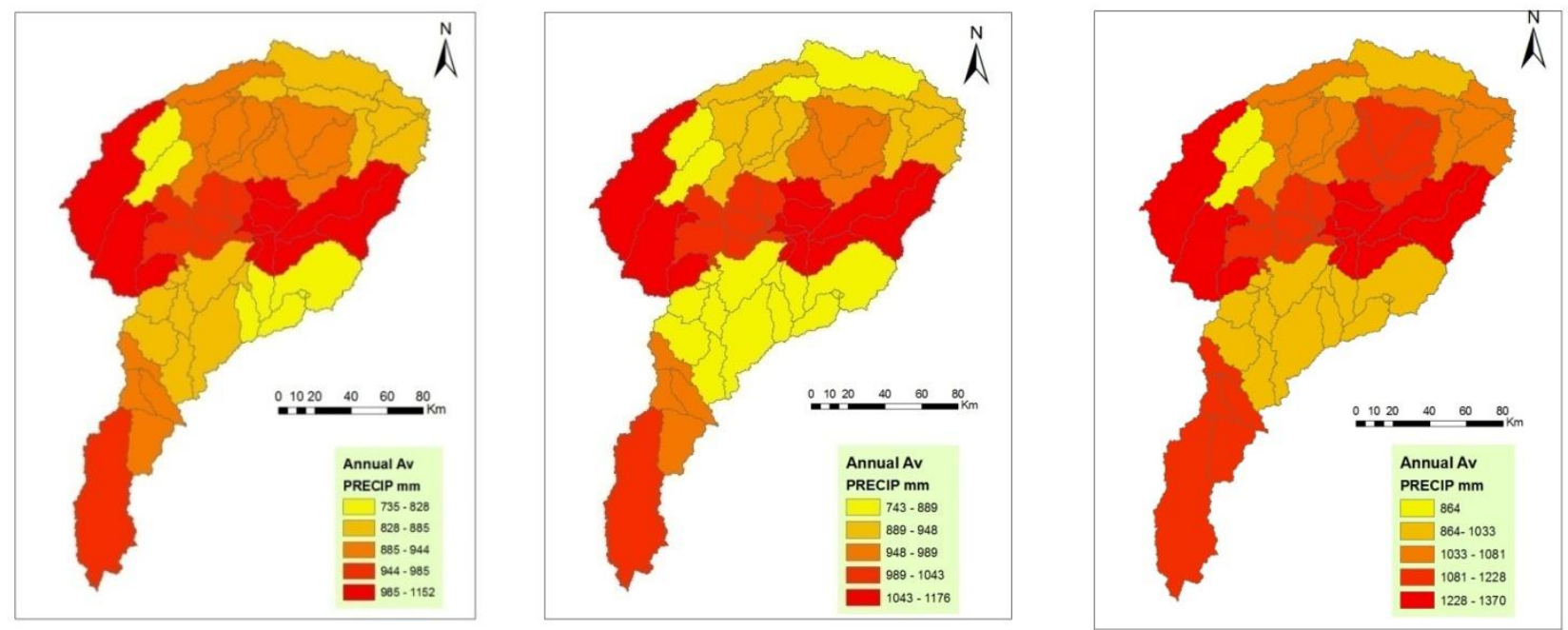

Fig. 3.3. Average annual PRECP for baseline 1961-1990, midcentury 2021-2050 and endcentury 2071-2098.

The calibrated and validated SWAT model has been applied to simulate hydrologic components of the Sind River Basin for Baseline period (1961-1990), Midcentury (2021-2050) and Endcentury (2071-2098) periods for PRECIS; RCM extracted IPCC SRES A1B Climate Change
Scenarios. In all the hydrologic simulations, the generated weather data has been used because if there has been any bias in the generated weather data that would be consistent in both cases and thus prediction of the climate change would be more realistic. The present landuse characteristic has been 
assumed to be same for the future periods of simulation, because it is very difficult to predict exact future landuse characteristics by different extrapolation methods.

\section{B. Effect of Climate Change on Different Hydrological Regimes of Sind River Basin}

\section{1) Annual average water yield (WYLD)}

Water yield is largely dependent on the amount of rainfall on its watershed area and the actual evapotranspiration amount released into the atmosphere. Therefore the climate change through precipitation and temperature can considerably influence on annual soil moisture patterns. The simulated average annual water yield for the baseline, midcentury and end century periods are presented in Fig. 3.1, $3.2 \&$ 3.3. Fig. 3.1 shows that during baseline period, the annual water yield for most of the sub basin areas of the watershed varies from $42 \mathrm{~mm}$ to $15493 \mathrm{~mm}$ under baseline period (1961-1990) and for the whole watershed from baseline to end century it ranges between $42-17501 \mathrm{~mm}$. Annual water yield in midcentury is likely to increase under the projected climate scenario and it could vary between 46 $\mathrm{mm}$ to $17351 \mathrm{~mm}$ within the watershed. The increase in water yield due to climate change in mid century compare to baseline period is by $12 \%$ and consequently to end century by $13 \%$ respectively. The eastern part of the watershed has been found to generate higher water yield in midcentury similar to the baseline period. However, the increase in midcentury water yield is about $100 \mathrm{~mm}$ for most of the eastern side sub watersheds, as also seen from the comparison of all three figures in Fig. 3.2. During the end century period the increase in average annual water yield in eastern and southern parts of the watershed by $200 \mathrm{~mm}$ when compare to the baseline and midcentury periods.

\section{2) Average annual evapotranspiration (ET)}

Spatial variations in average annual evapotranspiration (ET) for the baseline, midcentury and end century periods are shown in Fig. 3.2. There is a mild increase in ET $(2 \% 0$ during the mid century period compare to baseline and $6 \%$ increase in ET during end century period compare to base line due to feature climate change impact. The average annual ET during baseline period ranged between $73 \mathrm{~mm}$ and $313 \mathrm{~mm}$, and lower ET has been found in the sub watersheds located in the northwest and central part of the watershed during baseline. As a consequence of climate warming, the midcentury average annual ET could be between $107 \mathrm{~mm}$ and $1105 \mathrm{~mm}$ and higher rates of ET could occur in some sub watersheds located in the northwest and central part of the watershed during midcentury. Similarly in the end century average annual ET could be between $63 \mathrm{~mm}$ and $1148 \mathrm{~mm}$ and higher rate of increase in ET could occur in some sub watersheds located in the northwestern and central part of the watershed as shown in Fig. 3.2.

\section{3) Average annual precipitation (PRECP)}

In Fig. 3.3, there is an increase in average annual precipitation (PRCEP) of $14.0 \%$ from Baseline to Endcentury. However there is no variation in midcentury in overall but central part of sub basins receives more precipitation. Overall the increase in precipitation during end century covers mainly north central and southern parts of the sub watersheds. The increase in precipitation in end century indicates that more extreme high intensity events of flood and drought may be expected due to climate change. The annual average precipitation would be increased from baseline to midcentury by $2.0 \%$ and mainly the increase in northern and southern side sub watersheds. There is a decrease in precipitation from baseline to midcentury and these changes were seen in northeast and southern parts of sub watershed due to climate change. The minimum precipitation also increased by $18 \%$ from baseline to end century period due to global warming.

\section{CONCLUSIONS}

The SWAT model has been applied is well capable to simulate hydrological components of the Sind River Basin for prediction of future climate change. Simulation results show that water yield across the SRB varies from baseline to midcentury with an increase from $12-13 \%$ mainly covering central and southern parts of sub watersheds due to impact of climate change. During end century a projected increase of $13 \%$ water yield compare to baseline covering eastern to southern parts of sub watershed. The evapotranspiration (ET) across the SRB is increasing from baseline to mid century $(5 \%)$ and to end century $(6 \%)$ due to impact of future climate change. The reason for this could be increase in crop production due to increased demand and anthropogenic changes. The increase in precipitation in end century $(18 \%)$ indicates that more extreme high intensity events of flood and drought may be expected due to climate change. Rise in temperature up to $5^{0} \mathrm{C}$ during the month of October reduce the crop yields as it is a crop critical stage in khariff season.

\section{REFERENCES}

[1] L. N. Bcccipcc, "Climate change 2007: Impacts, adaptation and vulnerability: Contribution of working group II to the fourth assessment report of the intergovernmental panel," 2007.

[2] K. Eckhardt and U. Ulbrich, "Potential impacts of climate change on groundwater recharge and streamflow in a central European low mountain range," J. Hydrol., vol. 284, no. 1-4, pp. 244-252, Dec. 2003.

[3] S. Ashraf Vaghefi, S. J. Mousavi, K. C. Abbaspour, R. Srinivasan, and H. Yang, "Analyses of the impact of climate change on water resources components, drought and wheat yield in semiarid regions: Karkheh River Basin in Iran," Hydrol. Process., vol. 28, no. 4, pp. 2018-2032, 2013.

[4] M. Rahman, T. Bolisetti, and R. Balachandar, "Hydrologic modelling to assess the climate change impacts in a Southern Ontario watershed," Can. J. Civ. Eng., vol. 103, No. May, pp. 91-103, 2012.

[5] A. K. Gosain, S. Rao, and D. Basuray, "Climate change impact assessment on hydrology of Indian river basins," Current, vol. 90, no. 3, pp. 346-353, 2006.

[6] M. Faramarzi, K. C. Abbaspour, S. Ashraf Vaghefi, M. R. Farzaneh, A. J. B. Zehnder, R. Srinivasan, and H. Yang, "Modeling impacts of climate change on freshwater availability in Africa," J. Hydrol., vol. 480, pp. 85-101, Feb. 2013.

[7] C. Meng, J. Zhou, M. Dai, and W. Li, "An evaluation of the impact of climate change on runoff in the upper reaches of Yangtze River, China," Int. J. Environ. Sci. Dev., vol. 8, no. 6, pp. 417-420, 2017.

[8] B. Narsimlu, A. K. Gosain, and B. R. Chahar, "Assessment of future climate change impacts on water resources of Upper Sind River Basin, India using SWAT model," Water Resour. Manag., vol. 27, no. 10, pp 3647-3662, Jul. 2013.

[9] J. G. Arnold, R. S. Srinivasan, Muttiah, and J. R. Williams, "Large area hydrologic modeling And assessment part 1: Model development," J. Am. Water Resour. Assoc., vol. 34, no. 1, pp. 73-89, 1998. 
[10] S. L. Neitsch, J. G. Arnold, J. R. Kiniry, and J. R. Williams, "Soil and water assessment tool theoritical documentation," Texas Water Resources Institute, College Station, Texas, 2005, p. 476.

[11] D. N. Moriasi, J. G. Arnold, M. W. Van Liew, R. L. Bingner, R. D. Harmel, and T. L. Veith, "Model evaluation guidelines for systematic quantification of accuracy in watershed simulations," Trans. ASABE, vol. 50, no. 3, pp. 885-900, 2007.

[12] S. L. Neitsch, J. G. Arnold, J. R. Kiniry, R. Srinivasan, and J. R. Williams, "Soil and water assessment tool user's manual," Texas Water Resources Institute, College Station, Texas, 2002, p. 412.

[13] K. Eckhardt and J. G. Arnold, "Automatic calibration of a distributed catchment model," J. Hydrol., vol. 251, no. 1-2, pp. 103-109, 2001.

[14] T. Lenhart, K. Eckhardt, N. Fohrer, and H.-G. Frede, "Comparison of two different approaches of sensitivity analysis," Phys. Chem. Earth, Parts A/B/C, vol. 27, no. 9-10, pp. 645-654, 2002.

[15] C. Santhi, J. G. Arnold, J. R. Williams, L. M. Hauck, and W. A. Dugas, "Application of a watershed model to evaluate management effects on point and nonpoint source pollution," Trans. ASABE, vol. 44, no. 6, pp. 1559-1570, 2001.

[16] K. L. White and I. Chaubey, "Sensitivity analysis, calibration, and validations for a multisite and multivariable swat model," J. Am. Water Resour. Assoc., vol. 41, no. 5, pp. 1077-1089, Oct. 2005.

[17] A. Griensven, T. Meixner, S. Grunwald, T. Bishop, M. Diluzio, and R. Srinivasan, "A global sensitivity analysis tool for the parameters of multi-variable catchment models," J. Hydrol., vol. 324, no. 1-4, pp. $10-23,2006$

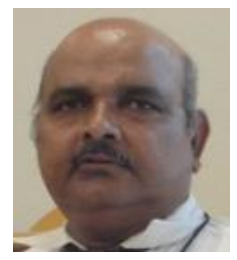

Boini Narsimlu was born in Hyderabad, India in June 1964. He completed his B.Tech degree in agricultural engineering from Andhra Pradesh Agricultural University (APAU), Hyderabad, India in 1988. He then completed his M.Tech in water resources from Jawaharlal Nehru Technological University, Hyderabad in 2000. He is a Ph.D student in water resources engineering, Indian Institute of Technology Delhi, New Delhi, India. His major is hydrological modeling and water resources management using SWAT model and MODFLOW. He has been working in Indian Council of Agricultural Research (ICAR)-Central Research Institute for Dryland Agriculture since 1989 as an Agricultural Engineer. And as a Senior Scientist in Soil and Water Conservation Engineering at ICAR-Indian Grassland and Fodder Research Institute, Jhansi, India from 2009. He has over 30 publications, including 12 publications in reputed journal, including, Journal of irrigation and drainage engineering, Water resources management, Environmental processes, Water resources research, Soil Science Society of America Journal, Modeling Earth Systems and Environment and European Journal of Soil Science. His three important publications are: (1) Narsimlu, B., Gosain, A.K., Chahar, B.R., 2013. Assessment of Future Climate Change Impacts on Water Resources of Upper Sind River Basin, India Using SWAT Model. Water Resour. Manag. 27. doi:10.1007/s11269-013-0371-7, (2) Narsimlu, B., Gosain, A.K., Chahar, B.R., Singh, S.K., Srivastava, P.K., 2015. SWAT Model Calibration and Uncertainty Analysis for Streamflow Prediction in the Kunwari River Basin, India, Using Sequential Uncertainty Fitting. Environ. Process. 2. doi:10.1007/s40710-015-0064-8 and (3) Narsimlu, B., Rao, B.V., Mishra, P.K., Rao, K.V., 2004. Effect of covers for soil and water conservation using tilting flume. J. Irrig. Drain. Eng. 130. doi:10.1061/(ASCE)0733-9437(2004)130:2(154). His research interest includes Soil and water conservation, Hydrology, Watershed management and Hydrologic modeling using SWAT model and MODFLOW.

Boini Narsimlu is a Life Member of the Institution of Engineers, India, (IEI) and Indian society of Agricultural Engineers, (ISAE) India. Life Member of Range Management Society of India, RMSI.He is currently working as a Scientist in Soil and Water Conservation Engineering at ICAR-Central Research Institute for Dryland Agriculture, Hyderabad, India.

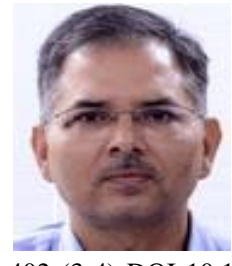

Bhagu R. Chahar is a professor in the Department of Civil Engineering, Indian Institute of Technology Delhi, New Delhi, India. $\mathrm{He}$ has over 109 publications including selected three are: (1) Gaur, S., Chahar, B.R., and Graillot, D. (2011). "Analytic Elements Method and Particle Swarm Optimization based Simulation-Optimization Model for Groundwater Management.” Journal of Hydrology, 402 (3-4) DOI 10.1016/j.jhydrol.2011.03.016, (2) Swamee, P.K., Mishra, G.C. and Chahar, B.R. (2000). "Design of minimum seepage loss canal sections." Journal of Irrigation and Drainage Engineering, 126(1):28-32, DOI 10.1061/(ASCE)0733-9437(2000)126:1(28), (3) Chahar, B. R. (2007). "Optimal Design of a Special Class of Curvilinear Bottomed Channel Section." Journal of Hydraulic Engineering 133(5), DOI 10.1061/(ASCE)0733-9429(2007)133:5(571). His areas of interest are: Canal design, Groundwater modeling and recharge, Seepage and drainage, Stream-aquifer interaction and Optimization.

Prof. Chahar is a Fellow of the Institution of Engineers (India), Fellow of the Indian Society for Hydraulics, Fellow of the India Water Works Association, Fellow of the Indian Water Resources Society and Member of American Society of Civil Engineers. He was recipient of Visiting International Fellowship-2013 by EWRI of ASCE, AICTE Career Award for Young Teacher - 2001, and DST - SERC Young Scientist award - 2003.

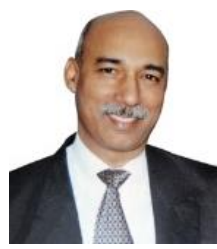

Ashvani K. Gosain is a professor in the Department of Civil Engineering, Indian Institute of Technology Delhi, New Delhi, India. He has over 150 publications with over 50 publications in peer reviewed journal, including, International Association of Hydrological Sciences, International Journal of Environmental Research and Development, Water resources management, Current Science, Hydrological Processes, and Journal of Hydrology. His three important publications are: (1) Dasgupta, S. Gosain, A.K., Rao, S., Roy, S. and Sarraf, M. (2013). "A megacity in a changing climate: the case of Kolkata." Climatic Change, Vol. 116 (3), pp 747-766. (2) Gosain, A. K., Sandhya Rao, and Debajit Basuray (2006). Climate change impact assessment on hydrology of Indian river basins, Current Science, Vol. 90 (3), pp 346-353. (3) Ambast, S. K., Keshari, A. K. and Gosain, A. K. (2005). A simple procedure for estimating distributed daily evapotranspiration using Landsat-TM data Photonirvachak, Journal of Indian Society of Remote Sensing, Vol. 33, No 1, pp 39-49. His area of interest in Integrated Watershed Modelling, GIS, Hydrological Modelling, Irrigation Management, Climate Change, Environmental Impact Assessment.

Prof. Gosain made a significant contribution to the NATCOM - the National Communication of India to the UNFCCC (http://gisserver.civil.iitd.ac.in/natcom). Prof. Gosain has successfully delivered many prestigious World Bank, ADB and European Union Projects besides a large number of national projects. Seventeen students have completed their Ph.D. under his supervision. One of the important assignments of Prof. Gosain include the formulation of the Ganga River Basin Management Plan (GRBMP), of which he was the Team Leader of the Water Resources Management group. He has also formulated the Drainage Master Plan of NCT of Delhi for the Delhi Government. He is also part of the expert committees appointed by the Honourable National Green Tribunal to suggest solutions to deal with the ever increasing pollution levels in Yamuna and Ganga. 